\begin{tabular}{|c|c|}
\hline & $\begin{array}{l}\text { International Journal of Trend in Scientific } \\
\text { Research and Development (IJTSRD) }\end{array}$ \\
\hline 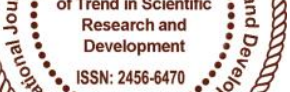 & International Open Access Journal \\
\hline 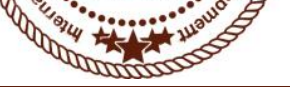 & ISSN No: $2456-6470 \mid$ www.ijtsrd.com | Volume - 2 | Issue -4 \\
\hline
\end{tabular}

\title{
A Study on Performance Evaluation of Selected Diversifing of Mutual Funds Equity Schemes
}

\author{
${ }^{1}$ Dr. S. P. Dhandayuthapani, ${ }^{2}$ M. K. Sindhu \\ ${ }^{1}$ Assistant Professor, ${ }^{2}$ Final year PG Student \\ ${ }^{1,2}$ Department of Management Studies, \\ ${ }^{1,2}$ Anna University (BIT Campus), Tiruchirappalli, Tamil Nadu, India
}

\begin{abstract}
Indian capital market give with a multiplicity of investment alternatives for investors to assist them in different investment tools and to make certain the profitable return .Daily closing Net Assets value of similar schemes has been use to calculate the returns from the fund schemes. The main objective of this study work is the financial performance of selected mutual funds schemes through the statistical parameter such as (beta, standard deviation, coefficient of determination, Sharpe ratio). This study is intended to evaluate performance of mutual funds and also the role of asset management companies in reference to private sectors and public sectors. The findings of this study will supportive to investors and their investment decisions in future.
\end{abstract}

Keywords-- Mutual funds, performance evaluation, Sharpe calculate, Jensen calculate Treynor calculate.

\section{INTRODUCTION}

Mutual Fund is the pool of the money, based on trust who invests the saving of a number of investors who shares a common financial goal, like the capital appreciation and divided earning. The increase money is used in different securities like stock, bond, funds markets \& commodities. Each mutual fund has general financial goal and the money is invested in accordance with the idea. Fund is managed by a professional fund manager, who is responsible for apply a fund's investing strategy and managing its portfolio trading performance. Each investor in the mutual fund participate proportionally (base upon the number of shares owned) in the gain or loss of the stock. Any investor can invest minimum amount that is practical and diversify their portfolio in different sectors depending upon their interests and risks.

\section{LITERATURE REVIEW}

(Dr.R.Narayanasamy,2013)A mutual fund is a professionally managed type of collective investment scheme that pools money from many investors and invests it in stocks, bonds, short-term money market 2 instruments and other securities. Sahiljain ( 2012).Svjsnvks

A mutual fund pools together the savings of such small investors and invests the same in the capital market and passes the benefits to the investors .Dr.Vikaskumar (2011).

A Mutual Fund is a trust that pools the savings of a number of investors who share a common financial goal. a Mutual Fund is the most suitable investment for the common man as it offers an opportunity to invest in a diversified, professionally managed basket of securities at a relatively low cost. Deepak Agarwal (2014).

Mutual Funds have become a widely popular and effective way for investors to participate in financial markets in an easy, low-cost fashion, while muting risk characteristics by spreading the investment across different types of securities, also known as diversification .Prof. Kalpesh Prajapti (2015).

A mutual fund is a pool of money collected from many small investors which is professionally managed by the portfolio managers. It is a type of collective investment scheme and invests it various securities such as in stocks, bonds and short-term money market instruments. The performance of the fund depends upon the economic condition of the country and the world as a whole. Dr.S.Vasanthal, Uma maheswari (2014). 
Small investors look at mutual funds as safest avenue to enter equity markets. They expect that the fund management with large Assets under Management (AUM), professional managers, low transaction fees, access to information, and ability to forecast the markets will fetch them more returns than a naïve investment strategy. These expectations of small investors lead to large volumes of research on performance of mutual funds. Dr. Y.Rama Krishna (2011).

A mutual fund is a professionally-managed firm of collective investments that pools money from many investors and invests it in stocks, bonds, short-term money market instruments, and/or other securities. In a mutual fund, the fund manager, who is also known as the portfolio manager, trades the fund's underlying securities, realizing capital gains or losses, and collects the dividend or interest income. Suchita Shukla (2013).

Mutual fund industry today is one of the most attractive investment avenues in India. Mutual fund is a good investment option for the medium and small investors who have limited resources and do not have professional knowledge about stock market and other investment opportunities. Mutual funds are the significant financial intermediary collecting funds mainly from small investors and investing them in financial market securities. A mutual fund is an investment company or trust that pools the resources of thousands of its shareholders or unit holders and invest it on behalf of these diversified securities and a cross section of companies to attain the objectives of the investors. Dr. S. Narayana Rao(2012)

A mutual fund is just the connecting bridge or a financial intermediary that allows a group of investors to pool their money together with a predetermined investment objective. The mutual fund will have a fund manager who is responsible for investing the gathered money into specific securities (stocks or bonds). An investor while investing in mutual funds buys units or portions of the mutual fund and thus on investing becomes a 3 shareholder or unit holder of the fund. Dr. R. Karrupasamy.

\section{OBJECTIVES OF THE STUDY}

$\square$ To identify the performance of open ended equity mutual funds schemes

To measures the performance of mutual fund companies
To analysis the risk returns parameter for mutual fund performance

To study the use of evaluate the future investment about open ended equity schemes

\section{SCOPE OF THE STUDY}

The present study involves of 20 mutual funds schemes by diverse sector. The time of this period of this research work is from April 2013 to March 2017. The NAV of the selected schemes have been compared for five year with an annual return.

\section{RESEARCH METHODOLOGY}

\section{A. Research design}

The quality of any research project will be improved by a well appreciative of research design. Research design is the approach of systematic collection of data and analysis of data which is related to the objective of the research project. For this research study descriptive research design has been applied and also data collection is secondary data sources of information. The process of collecting secondary data was collected from the Association of mutual fund India, BSE India etc. Initially this study tries to evaluate the performance of the 20 equity mutual fund schemes.

\section{B. Data sources}

For the study, the collecting secondary data was collected from the Association of mutual fund India, BSE India etc. Initially this study tries to evaluate the performance of the 20 equity mutual fund schemes.

\section{Tools and techniques used}

Analysis has been done by using following statistical tools.

1. Sharpe ratio: It indicates the risk-return performance of portfolio.

Portfolio Average Return (Rp) - Risk Free

Rate of Return (RF)

Sharpe Index =

Standard Deviations of the Portfolio Return

2. Treynor ratio : It measure the returns earned in excess of that which could have been earned on investment that has no diversifiable risk.

Portfolio Average Return(RP) - Risk Free Rate

of Return (RF)

Treynor Index = 
International Journal of Trend in Scientific Research and Development (IJTSRD) ISSN: 2456-6470

Beta Coefficient of Portfolio

3. Jensen ratio : It measures the risk-adjusted performance of a security or portfolio in relation to the expected market return .

$\operatorname{Alpha}(\alpha)=(R x-R f)-\beta(R m-R f)$

4. Beta : It measures the volatility or systematic risk of a security with comparison to the market as a whole.

Beta is calculated as,

Covariance $(\mathrm{Rx}, \mathrm{Rm})$

$\beta=$

Variance $(\mathrm{Rm})$.

\section{Data analysis and interpretation}

\begin{tabular}{|c|c|c|c|c|}
\hline $\begin{array}{l}\text { Table1: Analysis of risk, } \\
\text { return, and beta S.no }\end{array}$ & 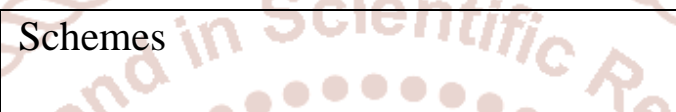 & Return & Risk & Beta \\
\hline 1 & Sbi banking \& financial fund & 0.4687 & 0.0390 & 0.5949 \\
\hline 2 & Sbi diversity equity fund & 0.3965 & 0.0330 & 0.4426 \\
\hline 60 & Sbi magnum equity fund & 0.1673 & 0.0139 & 0.3265 \\
\hline 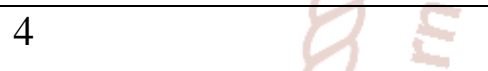 & Sbi infrastructure equity fund & -0.0396 & -0.0033 & 0.7027 \\
\hline 0 & Reliance diversified power sector fund & 1.0419 & 0.0868 & 0.9619 \\
\hline 3 & Reliance infrastructure fund & 0.7827 & 0.0652 & 0.5925 \\
\hline 8 & Uti banking sector fund ment & 0.8091 & 0.0674 & 0.6851 \\
\hline 8 & Hdfc growth fund & 0.8426 & 0.0702 & 0.6875 \\
\hline 9 & Icici infrastructure fund & 0.7396 & 0.0616 & 0.6354 \\
\hline 10 & Hdfc index fund & 0.1378 & 0.0114 & 0.26 \\
\hline 11 & Hdfc infrastructure fund & 0.7282 & 0.0606 & 0.6916 \\
\hline 12 & Uti infrastructure fund & 0.3308 & 0.0275 & 0.4477 \\
\hline 13 & Hdfc equity saving fund & 0.4373 & 0.0364 & 0.6285 \\
\hline 14 & Axis saver equity fund & -0.1570 & -0.0130 & 0.0869 \\
\hline 15 & Axis equity fund & -0.0403 & 00.0033 & 0.3275 \\
\hline 16 & Axis long term equity fund & 1.1805 & 0.0983 & 0.7397 \\
\hline 17 & L\&T infrastructure fund & 1.0430 & 0.0869 & 0.7251 \\
\hline 18 & Tata india consumer fund & 05960 & 0.0496 & 0.6470 \\
\hline 19 & Tata resources \&energy fund & 0.7700 & 0.0641 & 0.6283 \\
\hline 20 & Brila sunlife infrastructure fund & -0.0636 & -0.0636 & 0.2075 \\
\hline
\end{tabular}

VI. INFERENCE

Its represent the result of sharpe measure and Treynor measure observed from the above table higher 
positive value sharpe measure as found in reliance diversified power sector fund (2.4768) which followed by Axis long term equity fund (2.4257) and L\&T infrastructure fund (2.2155).the study, the sharper ratio was positive for all schemes which showed tats funds were providing returns for all schemes risk free rate. In Treynor measure, the table 2 that 2 schemes out of 5 had outperformance the benchmark HDFC growth fund is the top performed which followed by HDFC equity fund. In Jensen measure of the mutual fund schemes that showed positive alpha which indicated superior performance of the schemes and remaining 4 schemes negative alphas.

\section{CONCLUSION}

The study of investigates the performance of 20 open ended schemes diversified equity schemes for the period of April 2013 to March 2017 (five years) of transition economy. Daily closing Net Assets value of similar schemes has been use to calculate the returns from the fund schemes. The historical performance of the selected schemes were evaluated on the basis of sharpe, Treynor, Jensen measure whose result will be useful for investors for taking better investment decisions.

\section{References}

[1] Arathy B,Aswathy A nair,,Anju sai. P,Pravitha .N.R. (2015). A study on factors affecting investment on mutual funds andd its preference of retail investor (Vol. 5). Amirtha vishwav vidyapeetham: International journal of scientific and research publication.

[2] C.Jensen, M. (2002). The performance of mutual funds (Vol. 23). Journal of finance.

[3] Deepakagrawal. (2008). Measuring performance of India mutual funds. Indore: socail science research network.

[4] Dr.B.Nimalathasan , Mr.R.Kumar Gandhi. (2012). Mutual fund financial performance analysis-A comparative study on equity diversified schemes equity mid cap schemes.
Srilanka: EXCEL International Journal of Multidiciplinary Management studies.

[5] Dr.R.karrupasamy,Mrs.V.Vanaja. (coimbatore). Performance evaluation of selected category of public sector mutual fund schemes in indi (Vol. 1). 2014: International research journal of business and management.

[6] Dr.R.Narayanasamy, v.rathnamani. (2013). Performance evalution of equity mutual funds(on selected equity large cap funds) (Vol. 2). Trichy: International journal of business and management invention.

[7] Dr.S.Narayanrao. (2003). Performance evaluation of india mutual funds. mumbai: National stock exchange in india.

[8] Dr.s.vasantha,uma maheshwari,K.subashini. (2013). Evaluating the performance of some selected open ended equity diversified mutual fund in india mutual fund industry (Vol. 2). chennai: International journal of innovative research in science.

[9] Dr.Sarita bahl, Meenakshi rani. (2012). A comparative analaysis of mutual fund schemes in india (Vol. 1). Ludhiana,Haryana: International journal of marketing financial service \&management research.

[10] Dr.Sarita bahl, Meenakshi rani. (2012). A comparative analaysis of mutual fund schemes in india (Vol. 1). Ludhiana,Haryana: International journal

[11] http://www.amfi.com

[12] http://www.bseindia.com

[13] http://www.utifund.com

[14] http://www.mutualfundsindia.com

[15] http://www.sebi.gov.in

[16] http://articles.economictimes.indiatimes.com/2 012-01-16/news/30631892_1_mutual-fund-fundmanagement-closed-ended

[17] http://www.academia.edu/4414516/Mutual_fu nd_research_paper

[18] http://www.investopedia.com/articles/basics/0 3/040403.asp 